of books about naval strategy and tactics. His work has been largely overlooked, although it was used by great authors like Bernard Brodie.

The influence of Clausewitz is readily observable as Vego elaborates of on his core arguments. For example, in Chapter 4, Elements of Naval Tactical Actions, the author brings the concept "center of gravity" to the discussion, examining the origins and meaning of the term as he explains the "tactical center of gravity" in naval action. It is very refreshing to see Vego apply Clausewitian concepts with objectivity and clearness, while creating his own approach to naval tactics.

This is a must-have book for anyone who is interested in or more deeply researching the topic. It might, however, require several readings to absorb the ideas Vego presents in order to comprehend the full picture. This is a book to lean on, study, and explore. Naval tactics are an art, requiring years of comprehensive reading to command and depth of experience to execute. General Naval Tactics contributes to the never-ending mission of improving naval thought, while also providing the tools for enhancing experience at sea.

Andrea L. F. Resende de Souza Belo Horizonte, Brazil

Jamin Wells. Shipwrecked. Coastal Disasters and the Making of the American Beach. Chapel Hill, NC: University of North Carolina Press, www.uncpress. org, 2020. xiii +242 pp., illustrations, maps, notes, bibliography, index. US \$29.95, paper; ISBN 978-1-4696-60905. (E-book available.)

Shipwrecked presents several new perspectives on the changing history of the American east coast, focusing on the mainly sand shorelines between the Carolinas and Cape Cod. Chapters are devoted to telling a story of the taming of the American beach in the nineteenth century and presenting a fresh application of the frontier thesis to the area of contact between land and sea, far from the standard view of a steadily westward moving border between the settled and the wild.

Identified by the publisher as "Environmental History," this is indeed a volume about place but is environmental only in as much as the human action takes place in a defined locale. In reality, most of the chapters are about very specific activities in defined parts of the coastline. The approach allows for a detailed treatment of marine and near-marine activities over time which Wells then generalizes across the whole area. An overview of the history of the coast opens the volume with a view of the shore as "an isolated, parochial, pre-industrial space on the margins...." (36). The rest of the book deals with how and why that view changed over the century. The first of the stories to be examined is the history of wreckers and wreck law on the Jersey Shore which looks at the perceptions, and more importantly, the reality of shipwreck and salvage through the first half of the century. Wells traces the pragmatic and gradual application of regulation to balance private and community interests. The theme of transformation carries over to the examination and development of lifesaving mechanisms on the shoreline of Rhode Island and it is in this chapter that the idea of coastal tourism and its association with wrecks is more fully explored.

However, rather than looking at the rise of the seaside resort, the linkage here is to the federal presence of the US Life Saving Service. A chapter on the salvage activities in the coastal areas adjacent to the Port of New York extending from Cape Cod to Cape May concentrates on the gradual shift away 
from wreck so that the disappearance of debris and wrecks from the shore results in a pristine playground devoid of shipwreck. By the end of the century the once common phenomena of the wrecked ship had become a rare event seldom seen by the shoreside visitor. The rarity of shipwreck and emergence of the disaster tourist is the subject of another chapter in which shipwreck becomes spectacle as Wells recounts the activities surrounding the 1896 grounding of the steamship St. Paul at a seaside resort in New Jersey. The event became an intense and short-lived attraction near enough to cities for special tourist trains to run, but when the vessel was successfully hauled off the sands after ten days it was soon forgotten.

The volume rises from Wells' $\mathrm{PhD}$ thesis and large sections of three of the five main chapters have been previously published (one of these, on changing perceptions of marine salvage, appeared in The Northern Mariner in 2007). The individual chapters are extremely useful in presenting the history of their subjects, be it disaster tourism, lifesaving responsibilities, or the development of wreck and salvage operations. The book is less successful in gathering these threads together to support the assertion that shipwrecks and their associated infrastructure and management were responsible in great measure for the development of coastal tourism. Wells skillfully shines a light on factors which have not been previously considered such as regulation of coastal activities, but in his advocacy for these factors as being preeminent in the taming of the coastal frontier, he may be understating other more general societal drivers such as the emergence of a middle class and their increased leisure time and travel. Indeed, the development of tourism at the shore occurred at a time when Americans were explor- ing many parts of their own hinterlands, not just the beach.

As behooves a study which began as a thesis, the volume is extremely well-researched. A full one-fifth of the volume consists of notes and bibliography. Wells has made extensive use of primary archival sources to ground richly detailed case studies as the basis for more general observations across the region. For example, the Forman Family Papers from New Jersey's Monmouth County Historical Association give in-depth information about the role of the local commissioners of wrecks on the Jersey Shore which introduces the discussion of the changes in regulation of salvage responsibilities throughout the nineteenth century. The William Saunders papers in the Mystic Seaport Museum play a similar role in setting the scene for the chapter linking lifesaving activities and tourism.

The volume, overall, is successful in its parts, less so in the whole. The reader will have access to excellent summaries of the background to, and effectiveness of, the interventions of local, state, and federal governments in preventing shipwrecks, and in managing the human and economic consequences when they did occur. Wells enlivens what could be a dry administrative history treatment by telling the stories of fascinating individuals engaged in the process. The chapters, which are more like a series of linked essays, will stimulate the reader to further ponder the question Wells considers in the book: how did human factors change America's nineteenth century perception of the beach from a place of peril to a place of pleasure? The volume is recommended for anyone interested in the human history of coastal regions.

\section{H.T. Holman}

Charlottetown, Prince Edward Island 